\title{
PENGARUH MODEL PEMBELAJARAN DAN KESADARAN METAKOGNITIF TERHADAP HASIL BELAJAR PESERTA DIDIK SMA DALAM MATERI POKOK ASAM BASA
}

\author{
Wiwiek Tamsyani \\ Mahasiswa Prodi Pendidikan Kimia \\ Program Pascasarjana, Universitas Negeri Makassar \\ email:wiwiek_syam@yahoo.com
}

\begin{abstract}
ABSTRAK
Penelitian bertujuan mengkaji hasil belajar penyebaran dengan model pembelajaran penemuan dan inkuiri terbimbing menggunakan rancangan quasi eksperimen dengan desain faktorial $2 \times 2$. Dilaksanakan di SMA Negeri 2 Takalar. Sampel dipilih dengan random sampling teknik acak kelas terdiri atas 2 kelas. Kelas XI IPA 1 (34 peserta didik) sebagai kelas eksperimen 1 dibelajarkan dengan model pembelajaran penemuan dan kelas XI IPA 2 (33 peserta didik) sebagai kelas eksperimen 2 dibelajarkan dengan model pembelajaran inkuiri terbimbing. Instrumen penelitian yaitu, angket Inventori Kesadaran Meta kognitif dan tes hasil belajar. Penggunaan program SPSS versi 20.0 menunjukkan bahwa 5 soal essay valid dengan reliabilitas sebesar instrumen sebesar 0.699. Data penelitian dianalisis pada taraf signifikan $\alpha=0.05$ dengan uji anova dua jalur. Hasil penelitian menunjukkan (1) Rata-rata nilai hasil belajar peserta didik yang menggunakan model pembelajaran penemuan, hasilnya lebih tinggi dibandingkan dengan model pembelajaran inkuiri terbimbing. (2) Rata-rata nilai hasil belajar peserta didik dengan kesadaran metakognitif tinggi, hasil belajar peserta didik lebih tinggi dibandingkan dengan rata-rata nilai hasil belajar dengan kesadaran metakognitif rendah. (3) Terjadi interaksi antara model pembelajaran dan kesadaran metakognitif dalam mempengaruhi hasil belajar SMA Negeri 2 Takalar. Jadi, ada pengaruh antara model pembelajaran dan kesadaran metakognitif terhadap hasil belajar peserta didik SMA Negeri 2 Takalar dalam materi pokok asam basa.
\end{abstract}

Kata kunci: inkuiri terbimbing, penemuan, metakognitif, hasil belajar

\begin{abstract}
The objective of this research is to determine the effect learning outcomes by dissemination of the questionnaire metacognitive awarenes inventory who are taught in discovery learning and guided inquiry learning which used quasi experimental with factorial design $2 \times 2$. The research was done in SMAN 2 Takalar. The sample was taken by random sampling technique. It consists of two classes, XI-IPA 1 (34) as experiment class 1 that taught in discovery learning and XI-IPA 2 (33) as experiment class 2 that taught in guided inquiry learning. The instruments that used in this research were questionnaire of metacognitive awareness inventory and learning outcome test. By using the Statistical Package for Social Sciences program version 20.0 for windows showed that 5 items of essay valid with content the reliability was 0.699 and the data were analyzed at significant level $\alpha=0.05$ by two way ANOVA. The results showed that (1) the average value of learning outcomes of SMAN 2 Takalar that uses the discovery learning, the result higher or better compared to the use the guided inquiry learning, (2) the average value of learning outcomes of SMAN 2 Takalar with awareness of metacognitive high, learning outcomes of is higher or better compared with an average value of learning outcomes with awareness of metacognitive low, and (3) there interaction between learning models and metacognitive awareness to the effect learning outcomes students of SMAN 2 Takalar in the subject matter acid and base. Therefore, the effect of learning models and metacognitive awareness on the learning outcomes students of sman 2 takalar the subject matter of acid and base.
\end{abstract}

Keywords: guided inquiry, discovery, metacognitive and learning outcomes 


\section{PENDAHULUAN}

Kualitas sumber daya manusia merupakan prasyarat bagi kemajuan suatu bangsa khususnya sekolah. Kualitas sumber daya manusia tergantung pada kualitas pendidikannya. Kualitas pendidikan tergantung pada tingkat kesadaran peserta didik dalam proses pembelajaran yang diberikan oleh guru di sekolah. Proses pembelajaran merupakan suatu kegiatan yang melibatkan dua pihak yaitu pihak pendidik atau guru dan peserta didik. Guru sebaiknya tidak memberikan pengetahuan begitu saja tetapi sebagai pendidik harus mengajarkan pengetahuan, keterampilan dan moral terhadap peserta didik yang dapat memberikan manfaat dalam kehidupannya sehingga peserta didik mampu membangun sendiri pengetahuannya. Oleh karena itu, guru hanya bertindak sebagai fasilitator dalam proses pembelajaran yang membuat informasi lebih bermakna dan relevan dengan kehidupan peserta didik.

Fakta di sekolah menunjukkan bahwa pembelajaran kimia dianggap sebagai pelajaran yang cukup sulit dan menjadi masalah tersendiri bagi peserta didik. Hasil penelitian yang dilakukan para ahli menunjukkan banyak peserta didik dapat dengan mudah mempelajari mata pelajaran lain tetapi mengalami kesulitan dalam memahami konsep-konsep dan prinsip-prinsip pelajaran kimia. Fokus utama dari pembelajaran kimia selama ini adalah mendapatkan jawaban. Peserta didik menyandarkan sepenuhnya pada guru untuk menentukan apakah jawabannya benar sehingga setiap pelajaran kimia yang disampaikan di kelas lebih banyak bersifat hafalan tanpa pemahaman yang baik. Ketidaktahuan peserta didik mengenai kegunaan kimia dalam praktek sehari-hari menjadi penyebab lekas bosan dan tidak tertarik hingga pada akhirnya hasil belajar peserta didik rendah pada pelajaran kimia.

Rendahnya hasil belajar peserta didik disebabkan pembelajaran kimia yang kurang menarik dan terkesan sulit karena pada umumnya peserta didik menunggu pengetahuan dari gurunya tanpa berusaha melatih kemampuan yang dimilikinya sehingga peserta didik terlebih dulu merasa jenuh ataupun tidak suka untuk mempelajarinya. Hal ini berkaitan dengan masalah kualitas manajemen pelajaran kimia yang disajikan dalam kegiatan pembelajaran. Masalah yang sering dihadapi dalam belajar kimia, yaitu Guru perlu mengajarkan peserta belajar dengan mudah karena setiap guru berbeda dalam cara mengajar. Apalagi dalam pelajaran kimia, tidak semua peserta didik dapat berdiskusi hanya dengan membaca tentang bagaimana cara menyelesaikan soal kimia berdasarkan rumusrumus yang disajikan dalam buku (Slameto, 2010).

Sehubungan dengan hal itu dalam proses pembelajaran kimia di kelas sebaiknya menerapkan model pembelajaran yang sesuai. Hal ini dilakukan agar konsep-konsep kimia dapat dibangun dengan pemahaman peserta didik itu sendiri. Hal yang harus dilakukan guru adalah mendorong peserta didik untuk berfikir, bertanya, memecahkan masalah, mengemukakan ide, mendiskusikan ide bahkan menemukan sesuatu yang baru. Van de Walle (2006) mengatakan bahwa "Guru harus mengubah model pembelajarannya dari pembelajaran berpusat pada guru menjadi pembelajaran berpusat pada peserta didik (student centre)". Artinya, guru perlu mengubah kelas dari sekedar kumpulan peserta didik menjadi komunitas kimia, menjadikan logika dan bukti kimia sebagai pembenaran dan menjauhkan otoritas guru untuk menuntaskan kebenaran sehingga dapat mementingkan pemahaman daripada hanya mengingat prosedur (Purwanto, 2008).

Guru sebagai pendidik harus bisa menerapkan model pembelajaran yang mampu melibatkan peserta didik secara aktif dalam proses pembelajaran kimia di kelas. Guru harus mengubah pola pikir peserta didik dan mengajukan pertanyaan-pertanyaan yang membutuhkan analisis tinggi dalam penyelesaiannya. Beberapa pertanyaan yang diajukan selama diskusi bisa bermakna dan beragam. Mengajar dengan instruksi metakognitif berarti bahwa guru akan memikirkan bagaimana proses dalam mengaktifkan kesadaran metakognitif peserta didik (Hartman, 2001).

Pencapaian hasil belajar peserta didik tidak hanya dipengaruhi oleh tingkat pengetahuan guru terhadap materi pelajaran yang akan diajarkan, melainkan ditentukan oleh model pembelajaran yang digunakan dan kesadaran peserta didik itu sendiri selama proses pembelajaran berlangsung. Penerapan model pembelajaran yang baik dapat membantu peserta didik memahami pelajaran dengan baik pula (Slameto, 2010).

Salah satu model pembelajaran yang dapat membantu peserta didik dalam memahami 
pelajaran dengan baik adalah model pembelajaran penemuan (discovery learning). Model pembelajaran penemuan adalah model pembelajaran yang menekankan kepada peserta didik untuk menemukan sendiri permasalahan yang diberikan oleh guru. Model ini dianggap cocok diterapkan dalam pendidikan di Indonesia karena sesuai dengan perkembangan kurikulum di Indonesia yaitu dari kurikulum tingkat satuan pendidikan (KTSP) menjadi kurikum 2013. Oleh karena itu, model pembelajaran penemuan dianggap salah satu model pembelajaran yang cocok diterapkan dalam proses pembelajaran di sekolah (Lingyi, 2010).

Model pembelajaran penemuan adalah model pembelajaran yang bersifat "student centre" yaitu proses pembelajaran yang berpusat pada peserta didik. Proses pembelajaran banyak melibatkan peserta didik dalam rangka penemuannya dan mengasimilasi konsep serta prinsip-prinsip materi pokok asam basa. Pada model pembelajaran penemuan guru memberikan kesempatan kepada peserta didik untuk menjadi seorang scientist sehingga melalui kegiatan tersebut peserta didik akan menguasai proses penemuan dalam menemukan pengetahuan baru yang bermanfaat bagi dirinya. Model pembelajaran ini dapat digunakan sebagai salah satu alternatif dalam memperbaiki hasil belajar peserta didik. Sehubugan dengan itu, model pembelajaran penemuan ini diharapkan adanya saling ketergantungan secara positif diantara peserta didik dan permasalahan yang diberikan sehingga peserta didik memiliki kesadaran dalam mempelajari materi pelajaran dan pada akhirnya hasil belajar yang diharapkan dapat tercapai (Dahar, 2006).

Selain model pembelajaran penemuan, dikenal juga model pembelajaran inkuiri terbimbing. Model pembelajaran inkuiri terbimbing merupakan salah satu model pembelajaran yang berpusat pada peserta didik. Meskipun kedua model pembelajaran yang digunakan sama-sama berpusat pada peserta didik, tetapi dalam pelaksanaannya tetap dikontrol oleh guru mata pelajaran. Oleh karena itu, pada model pembelajaran inkuiri, seorang guru harus dapat mendesain pembelajaran sehingga peserta didik dapat lebih aktif mengikuti proses pembelajaran, misalnya dengan melakukan interaksi berupa tanya jawab atau pemberian resitasi selama proses pembelajaran berlangsung (Mulyasa, 2004).
Hal lain yang perlu diperhatikan guru dalam mengajarkan kimia adalah membangun kesadaran metakognitif peserta didik. Kesadaran metakognitif didefinisikan sebagai proses seseorang dalam belajar. Kesadaran metakognitif mempengaruhi seseorang dalam menyerap dan mengolah informasi sehingga akan mempengaruhi peserta didik dalam memperbaiki hasil belajar.

$\begin{array}{rrr}\text { Kesadaran } & \text { metakognitif } & \text { sangat } \\ \text { diperlukan untuk } & \text { kesuksesan } & \text { belajar. }\end{array}$ Sehubungan dengan itu, kesadaran metakognitif peserta didik mampu mengelola kecakapan kognitif dan mampu melihat kelemahannya sehingga dapat dilakukan perbaikan pada pembelajaran selanjutnya. Peserta didik mampu merancang, memantau dan merefleksikan proses belajar secara sadar, maka hakikatnya peserta didik dilakukan lebih percaya diri dan lebih mandiri dalam belajar. Kesadaran metakognitif memungkinkan peserta didik untuk melakukan perencanaan, mengikuti perkembangan dan memantau proses belajarnya (Wibowo, 2007). Oleh karena itu, peserta didik yang telah memiliki kesadaran metakognitif yang baik diharapkan mampu mempengaruhi hasil belajarnya kearah yang lebih baik.

Hasil penelitian menunjukkan bahwa dalam penerapan model pembelajaran perlu mempertimbangkan kesadaran metakognitif peserta didik karena model pembelajaran yang sesuai dengan kesadaran metakognitif peserta didik akan mampu membantu peserta didik dalam proses pembelajaran. Jika model pembelajaran yang diterapkan sesuai dengan kesadaran metakognitif peserta didik, maka proses penyerapan informasi menjadi lebih efektif sehingga diharapkan dapat berpengaruh positif terhadap hasil belajar peserta didik (Astikasari, 2011).

Materi asam basa dalam pelajaran kimia merupakan materi yang banyak mengandung konsep yang perlu dipahami oleh peserta didik. Materi asam basa menuntut pemahaman, keterampilan, dan latihan sehingga jika peserta didik tidak menguasai konsep yang terdapat di dalam materi, maka peserta didik tidak akan dapat membangun pengetahuan dan akibatnya dalam proses pembelajaran akan mengalami kesulitan. Dalam mengajarkan materi asam basa, dapat digunakan beberapa model pembelajaran seperti pembelajaran penemuan maupun inkuiri terbimbing. Kedua model pembelajaran ini 
diharapkan mampu mempengaruhi hasil belajar peserta didik.

Hasil wawancara yang dilakukan penulis dengan salah seorang guru bidang studi Kimia di SMA Negeri 2 Takalar, diperoleh bahwa cara belajar peserta didik umumnya masih kurang aktif. Peserta didik cenderung menunggu penjelasan dari guru daripada mengkaji materi secara mandiri. Peserta didik cenderung pasif dan hanya mencatat keterangan yang diberikan guru. Selain itu, nilai kimia yang diperoleh peserta didik SMA Negeri 2 Takalar berdasarkan dokumen salah seorang guru bidang studi kimia bahwa pada tahun ajaran 2013/2014 hanya sekitar $40 \%$ yang tuntas setiap kelasnya pada materi asam basa.

Berdasarkan uraian latar belakang, perlu dilakukan penelitian dengan memfokuskan pada pengaruh hasil belajar antara peserta didik yang diajar menggunakan model pembelajaran penemuan dan model pembelajaran inkuiri terbimbing pada kelas XI IPA SMA Negeri 2 Takalar, pengaruh hasil belajar antara peserta didik kesadaran metakognitif tinggi dan kesadaran metakognitif rendah pada kelas XI IPA SMA Negeri 2 Takalar, dan pengaruh antara selisih hasil belajar peserta didik kesadaran metakognitif tinggi dan kesadaran metakognitif rendah pada pembelajaran penemuan dengan selisih hasil belajar peserta didik kesadaran metakognitif tinggi dan kesadaran metakognitif rendah pada pembelajaran inkuiri terbimbing kelas XI IPA SMA Negeri 2 Takalar.

Hipotesis penelitian ini adalah (1) Terdapat perbedaan hasil belajar peserta didik yang diajar dengan menggunakan model pembelajaran penemuan dan model pembelajaran inkuiri terbimbing dalam materi pokok asam basa kimia kelas XI IPA SMA Negeri 2 Takalar (2) Terdapat perbedaan hasil belajar peserta didik yang memiliki kesadaran metakognitif tinggi dan kesadaran metakognitif rendah dalam materi pokok asam basa kiinia kelas IX IPA SMA Negeri 2 Takalar. (3) Terdapat perbedaan antara selisih hasil belajar peserta didik kesadaran metakognitif tinggi dan kesadaran metakognitif rendah pada pembelajaran penemuan dengan selisih hasil belajar peserta didik kesadaran metakognitif tinggi dan kesadaran metakognitif rendah pada pembelajaran inkuiri terbimbing pada materi pokok asam basa kimia kelas XI IPA SMA Negeri 2 Takalar"

\section{METODE PENELITIAN}

Penelitian ini merupakan quasi eksperimen (eksperimen semu). Desain yang digunakan dalam penelitian ini adalah desain faktorial 2 x 2 . karena semua faktor dikombinasikan atau disilangkan dengan tiap faktor lainnya yang ada dalam eksperimen. Desain ini menggunakan variabel bebas, model pembelajaran dibagi dua yaitu model pembelajaran penemuan dan model pembelajaran inkuiri terbimbing dan kesadaran metakognitif dibagi menjadi dua kategori yaitu kesadaran metakognitif rendah dan kesadaran metakognitif tinggi. Desain ini menjelaskan tentang bagaimana interaksi kesadaran metakognitif dan model pembelajaran terhadap hasil belajar peserta didik kelas XI SMA Negeri 2 Takalar dalam mata pelajaran kimia asam basa.

Waktu Penelitian dilakukan dari bulan Februari hingga Maret 2015. Tempat penelitian dilakukan di kela XI SMAN 2 Takalar.

Subjek penelitian ini melibatkan dua kelas eksperimen $(n=67)$ yang dipilih dengan teknik random sampling atau teknik acak kelas dari lima kelas XI yang ada di SMAN 2 Takalar dan tidak melibatkan kelas control.

Variabel bebas. Model pembelajaran (A) merupakan variabel bebas manipulatif yang terdiri atas dua bagian yaitu: model pembelajaran penemuan $\left(A_{1}\right)$ dan model pembelajaran inkuiri terbimbing $\left(\mathrm{A}_{2}\right)$. Kesadaran metakognitif (B) merupakan variabel bebas atributif yang terdiri atas dua bagian yaitu: kesadaran metakognitif tinggi $\left(B_{1}\right)$ dan kesadaran metakognitif rendah $\left(\mathrm{B}_{2}\right)$.

Varibel terikat dalam penelitian ini adalah hasil belajar peserta didik kelas XI SMA Negeri 2 Takalar tahun ajaran 2014/2015.

Penelitian ini dilaksanakan dengan 1 kali pertemuan untuk pemberian inventori berupa angket kesadaran metakognitif untuk masingmasing kelas eksperimen. Selanjutnya, 4 kali pertemuan proses belajar untuk setiap penerapan model pembelajaran. Kemudian, 1 kali pertemuan pemberian tes hasil belajar untuk masing-masing kelas eksperimen. Instrumen hasil belajar diberikan setelah perlakuan karena menurut informasi yang didapatkan oleh guru bidang studi kimia pada sekolah tersebut bahwa 
selama ini hasil belajar peserta didik belum bisa dikatakan berada pada kategori tinggi. Peserta didik di sekolah tersebut apabila di awal bab, jika ditanya mengenai materi yang dibawakan sebelumnya yang berkaitan dengan materi yang akan dibawakan berikutnya, peserta didik masih belum mampu menyerap semua materi sebelumnya. Jadi, peserta didik di sekolah ini belum mampu menyerap semua materi yang telah dipelajarinya. Lagi pula, bimbingan belajar atau privat kimia pada sekolah ini belum ada. Untuk melaksanakan model pembelajaran penemuan dan model pembelajaran inkuiri terbimbing, maka dibuat instrumen penelitian yang terdiri dari angket inventori kesadaran metakognitif, RPP, LKPD, dan tes hasil belajar. Angket inventori kesadaran metakognitif untuk kedua kelas model pembelajaran penemuan dan kelas inkuiri terbim0bing adalah sama. Penyebaran angket MAI ini untuk mengetahui kesadaran metakognitif peserta didik berada pada kategori tinggi atau rendah. RPP model pembelajaran penemuan dan model pembelajaran inkuiri terbimbing tentu berbeda. Hal ini berdasarkan pada langkah-langkah pembelajaran yang ada pada masing-masing model pembelajaran tersebut sedangkan LKPD yang dibuat pada model pembelajaran penemuan dan model pembelajaran inkuiri terbimbing sama.

Data yang diperoleh yaitu data tes hasil belajar peserta didik SMAN 2 Takalar. Instrumen yang digunakan dalam penelitian ini ada 4 macam yaitu instrumen angket inventori kesadaran metakognitif, rencana pelaksanaan pembelajaran (RPP), lembar kerja peserta didik (LKPD), dan tes hasil belajar peserta didik.

Teknik pengumpulan data dalam penelitian ini adalah dengan memberikan tes hasil belajar. Soal tes hasil belajar yang diberikan sama untuk masing-masing kelas. Instrumen yang digunakan mencakup semua indikator yang harus dicapai oleh peserta didik pada materi pokok asam basa kimia. Tes kesadaran metakognitif menggunakan MAI yang terdiri dari 52 item yang diberikan sebelum pembelajaran. Pengukuran kesadaran metakognitif ini menggunakan MAI yaitu kuisioner yang menggambarkan kesadaran peserta didik. Kesadaran metakognitif diperlukan untuk memahami bagaimana tugas itu dilakukan. Kuisioner ini terdiri dari 52 item pertanyaan yang masing-masing 4 item jawaban yaitu sangat benar (SB), benar (B), tidak benar (TB), dan sangat tidak benar (STB), dan tes hasil belajar peserta didik kimia disusun dalam bentuk essay yang terdiri atas 5 soal yang telah divalidasi dan dihitung realibilitasnya sebelum diujikan ke sampel penelitian.

Analisis Data untuk Inventori Kesadaran Metakognitif. Penilaian kesadaran metakognitif peserta didik diubah menjadi skor, dengan skala likert model skala empat (Ghazali, 2006), selanjutnya skor total dan rata-rata skor total dihitung untuk setiap item inventori kesadaran metakognitif. Skor total rata-rata setiap item dihitung dengan menggunakan rumus:

$$
\text { Nilai }=\sum \frac{\text { Skor yang diperoleh }}{\text { Skor total }} \times 100
$$

Skor total dan rata-rata skor total dihitung untuk setiap item inventori kesadaran metakognitif, selanjutnya skor akhir yang diperoleh dikonversi menjadi persentase dengan pedoman konversi pengkategorian (Blakey \& Spance, 2008) seperti tersaji pada Tabel 1

Tabel 1 Pedoman Pengkategorian Kesadaran Metakognitif

\begin{tabular}{cc}
\hline Nilai Skor & Kategori \\
\hline $0-71$ & Rendah \\
$72-100$ & Tinggi \\
\hline
\end{tabular}

Analisis statistik deskriptif digunakan untuk mendeskripsikan secara umum hasil belajar peserta didik pada materi pokok asam basa kimia untuk setiap kelas eksperimen, yang terdiri dari nilai rata-rata (mean), median, modus, standar deviasi, skor tertinggi, dan terendah. Analisis data penelitian ini diolah dengan menggunakan SPSS 20. Untuk mengetahui nilai hasil belajar peserta didik dapat menggunakan rumus sebagai berikut. Kriteria penilaian menggunakan rumus Arikunto (2006), yaitu:

$$
\text { Nilai }=\frac{\text { skor perolehan peserta didik }}{\text { skor maksimum }} \times 100
$$

Data perolehan hasil belajar peserta didik selanjutnya dikelompokkan berdasarkan lima kategori, dengan mengacu kepada kategori hasil belajar peserta didik yang dituliskan dalam Tabel 2

Tabel 2 Kriteria Hasil Belajar Peserta Didik 


\begin{tabular}{cc}
\hline $\begin{array}{c}\text { Interval } \\
\text { Skor }\end{array}$ & Kategori \\
\hline $0-39$ & Sangat rendah \\
$40-59$ & Rendah \\
$60-74$ & Sedang \\
$75-90$ & Tinggi \\
$91-100$ & Sangat tinggi \\
\hline
\end{tabular}

(Sumber: Slameto, 2010)

Untuk mengetahui ketuntasan hasil belajar peserta didik dibandingkan dengan kriteria ketuntasan minimal (KKM) yang berlaku di SMA Negeri 2 Takalar pada materi pokok asam basa kimia, seperti pada Tabel 3

Tabel 3 Kriteria Ketuntasan Hasil Belajar Peserta Didik

\begin{tabular}{cc}
\hline Interval Skor & Kategori \\
\hline $70-100$ & Tuntas \\
$0-69$ & Belum Tuntas \\
\hline
\end{tabular}

Sumber: SMA Negeri 2 Takalar

Analisis statistik inferensial digunakan untuk menguji kebenaran hipotesis yang diujikan. Sebelum melakukan analisis statistik inferensial, maka sebagai uji prasyarat dilakukan uji normalitas dan uji homogenitas dengan menggunakan program aplikasi statistik SPSS 20. Jika uji prasyarat memenuhi kriteria normal dan homogen maka digunakan statistik parametrik untuk analisis statistik inferensial, sebaliknya jika kriteria normal dan homogen tidak terpenuhi maka digunakan statistik nonparametrik.

Uji normalitas digunakan untuk mengetahui apakah data yang diteliti berasal dari populasi yang terdistribusi normal. Pengujian normalitas data hasil belajar peserta didik dihitung menggunakan bantuan SPSS 20 dengan analisis one-Sample-Kolmogorov-Smornov Test. Kriteria pengujian: apabila signifikan (p) yang diperoleh lebih besar dari $\alpha=0.05$ maka data tersebut berasal dari populasi yang terdistribusi normal dan sebaliknya.

Asumsi normalitas merupakan prasyarat kebanyakan prosedur statistika inferensial. Pada penelitian ini asumsi normalitas dieksplorasi menggunakan uji normalitas Lilliefors (Kolmogorov Smirnov) melalui SPSS 20 dengan taraf signifikansi $\alpha=0.05$. Bentuk hipotesis untuk uji normalitas adalah sebagai berikut:

$\mathrm{H}_{0}$ : angka signifikan (Sig) $>0,05$ maka

data berdistribusi normal
$\mathrm{H}_{1}$ : angka signifikan $(\mathrm{Sig})<0,05$ maka data tidak berdistribusi normal

Uji homogenitas digunakan untuk mengetahui apakah kedua sampel yang diambil berasal dari populasi yang homogen (mempunyai varians yang sama). Pengujian homogenitas dihitung dengan bantuan program SPSS 20 menggunakan analisis Levene's Test of Equality of error Variance. Dengan kriteria pengujian: jika signifikansi $(\rho)$ yang diperoleh lebih besar dari $\alpha=0.05$ maka data tersebut homogen.

Uji homogenitas digunakan untuk mengetahui distribusi data, apakah homogen atau tidak homogen. Uji homogenitas dilakukan dengan cara membandingkan varian terbesar dan varian terkecil dengan menggunakan table. (Santoso, 2008).

Sementara Akdon (2008) merincikan langkah-langkah uji homogenitas sebagai berikut:

Mencari nilai varian terbesar dan terkecil kemudian mencari $\mathrm{F}$ hitung dengan rumus:

$$
F_{\text {Hitung }}=\frac{\text { Varian Besar }}{\text { Varian Kecil }}
$$

Membandingkan nilai $\mathrm{F}_{\text {hitung }}$ dengan $\mathrm{F}_{\text {tabel }}$ dengan kriteria; jika $F_{\text {hitung }}<F_{\text {tabel }}$, maka varians adalah homogen dan uji komparatif dapat dilakukan.

Uji hipotesis. Dalam pengujian hipotesis, kriteria untuk menolak atau tidak menolak $\mathrm{H}_{0}$ berdasarkan $\mathrm{P}$-value adalah jika $\mathrm{P}$-value $<\alpha$ maka $\mathrm{H}_{0}$ ditolak dan jika $\mathrm{P}-$ value $\geq \alpha$ maka $\mathrm{H}_{0}$ tidak dapat ditolak. Dalam program SPSS 20 digunakan istilah significance yang disingkat $\mathrm{Sig}$ untuk P-value, dengan kata lain P-value = Sig

\section{HASIL DAN PEMBAHASAN}

\section{Hasil}

Hasil penelitian yang disajikan meliputi deskripsi hasil belajar peserta didik, deskripsi kesadaran metakognitif dan uji hipotesis.

\section{Pengujian Analisis Deskripsi}

\section{a. Deskripsi Data Penelitian}

Hasil analisis deskripsi untuk nilai hasil belajar dan kesadaran metakognitif peserta didik kelas XI IPA SMA Negeri 2 Takalar untuk kedua kelas yang diajar dengan model pembelajaran 
penemuan dan inkuiri terbimbing terlihat pada Tabel 4

Tabel 4 Deskripsi Hasil Belajar Peserta Didik yang diajarkan dengan Model Pembelajaran Penemuan dan Model Pembelajaran Inkuiri Terbimbing dengan Kesadaran Metakognitif Tinggi dan Rendah

\begin{tabular}{|l|c|c|c|c|}
\hline \multirow{2}{*}{$\begin{array}{c}\text { Statisti } \\
\text { k }\end{array}$} & $\begin{array}{c}\text { Kela } \\
\text { S } \\
\text { Pene }\end{array}$ & $\begin{array}{c}\text { Kelai } \\
\text { Inkui } \\
\text { ri } \\
\text { mua } \\
\text { Terbi } \\
\text { n } \\
\text { m- } \\
\text { bing }\end{array}$ & $\begin{array}{c}\text { Kesada } \\
\text { ran } \\
\text { Metako } \\
\text { (IP-nitif } \\
\text { TinA }\end{array}$ & $\begin{array}{c}\text { Kesada } \\
\text { ran } \\
\text { Metako } \\
\text { g-nitif } \\
\text { Rendah }\end{array}$ \\
\hline N & $\mathbf{1})$ & $\mathbf{2}$ & & \\
Mean & & & & \\
Median & 34 & & & \\
Varians & 76,24 & 33 & 36 & 31 \\
Std. & 75,00 & 70,30 & 76,89 & 69,16 \\
deviasi & 151,7 & 73,00 & 77,00 & 70,00 \\
Range & 0 & 88,34 & 102,79 & 127,67 \\
Nilai & 12,32 & 9,39 & 10,14 & 11,29 \\
minimu & 67,00 & 44,00 & 42,00 & 62,00 \\
m & 30,00 & 30,00 & 55,00 & 30,00 \\
Nilai & 97,00 & 92,00 & 97,00 & 92,00 \\
maxim & & & & \\
um & & & & \\
\hline
\end{tabular}

Tabel 4 mendeskripsikan hasil belajar peserta didik pada kelas yang diajar dengan model pembelajaran penemuan dan model pembelajaran inkuiri terbimbing dengan kesadaran metakognitif tinggi dan rendah. Pada tabel terlihat bahwa nilai rata-rata hasil belajar untuk kelas yang diajar dengan model pembelajaran penemuan lebih tinggi 76,24 dibandingkan dengan model pembelajaran inkuiri terbimbing 70,30. Sedangkan nilai ratarata hasil belajar peserta didik dari kesadaran metakognitif tinggi dan kesadaran metakognitif rendah, yaitu 76,89 dan 69,16.

Nilai tertinggi untuk kelas yang diajar dengan model pembelajaran penemuan adalah 97,00 sedangkan nilai terendahnya adalah 30,00 dan untuk kelas yang diajar menggunakan model pembelajaran inkuiri terbimbing nilai tertinggi 92,00 sedangkan nilai terendahnya adalah 30,00.
Pada kelas yang diajar dengan model pembelajaran penemuan mempunyal nilai varians yang lebih besar 151,70 dan kelas yang diajar dengan menggunakan model pembelajaran inkuiri terbimbing yang lebih kecil 88,34 . Hal ini menunjukkan data hasil belajar peserta didik pada kelas yang diajar dengan model pembelajaran penemuan lebih bervariasi dibandingkan dengan kelas yang menggunakan model pembelajaran inkuiri terbimbing.

Nilai tertinggi untuk nilai hasil belajar dari kesadaran metakognitif tinggi adalah 97,00 sedangkan nilai terendahnya adalah 55,00 dan untuk nilai hasil belajar dari kesadaran metakognitif rendah nilai tertinggi 92,00 sedangkan nilai terendahnya adalah 30,00. Pada kesadaran metakognitif tinggi mempunyal nilai varians yang lebih kecil 102,79 sedangkan pada kesadaran metakognitif rendah mempunyal nilai varians yang lebih besar 127,67. Hal ini menunjukkan data nilai hasil belajar peserta didik dari kesadaran metakognitif rendah lebih bervariasi dibandingkan dengan nilai hasil belajar peserta didik dari kesadaran metakognitif tinggi.

Deskripsi hasil belajar peserta didik berdasarkan model pembelajaran dan kesadaran metakognitif ditunjukkan pada Tabel 5

Tabel 5 Deskripsi Rata-rata Standar Deviasi (Simpangan Baku) dan Jumlah Anggota Sampel Setiap Kelompok untuk Skor Hasil Belajar Peserta Didik

\begin{tabular}{c|c|c|c}
\hline \multicolumn{3}{c}{ Hasil Belajar Peserta Didik } \\
$\begin{array}{c}\text { Model } \\
\text { Pembelajar } \\
\text { an }\end{array}$ & \multicolumn{2}{|c}{$\begin{array}{c}\text { Kesadaran } \\
\text { Metakognitif }\end{array}$} & \multirow{2}{*}{ Jumlah } \\
\cline { 2 - 3 } & $\begin{array}{c}\text { Tinggi } \\
\left(\mathbf{B}_{\mathbf{1}}\right)\end{array}$ & $\begin{array}{c}\text { Rendah } \\
\left(\mathbf{B}_{2}\right)\end{array}$ & \\
\hline $\begin{array}{c}\text { Pembelajara } \\
\text { n Penemuan }\end{array}$ & $\mathrm{X}=78,40$ & $\mathrm{X}=60,00$ & $\mathrm{X}=76,24$ \\
(Discovery & $\mathrm{SD}=$ & $\mathrm{SD}=20,0$ & $\mathrm{SD}=12,3$ \\
Learning) & 9,49 & 0 & 2 \\
$\left(\mathrm{~A}_{1}\right)$ & $\mathrm{N}=30$ & $\mathrm{~N}=4$ & $\mathrm{~N}=34$ \\
\hline $\begin{array}{c}\text { Pembelajara } \\
\text { n Inkuiri }\end{array}$ & $\mathrm{X}=69,33$ & $\mathrm{X}=70,52$ & $\mathrm{X}=70,30$ \\
Terbimbing & 3 & $\mathrm{SD}=9,29$ & $\mathrm{SD}=9,39$ \\
$\left(\mathrm{~A}_{2}\right)$ & $\mathrm{N}=6$ & $\mathrm{~N}=33$ \\
\cline { 1 - 2 } & $\mathrm{X}=76,89$ & $\mathrm{X}=69,16$ & \\
Jumlah & $\mathrm{SD}=10,1$ & $\mathrm{SD}=11,2$ & \\
& 4 & 9 & \\
\hline
\end{tabular}


Berdasarkan pada Tabel 5 terlihat bahwa rata-rata hasil belajar peserta didik yang diajar dengan model pembelajaran penemuan lebih besar dibandingkan nilai rata-rata peserta didik yang diajar dengan model pembelajaran inkuiri terbimbing adalah 76,24 dan 70,30. Nilai ratarata hasil belajar peserta didik untuk model pembelajaran penemuan dan model pembelajaran inkuiri terbimbing dari kesadaran metakognitif tinggi adalah 76,89 dan nilai rata-rata hasil belajar peserta didik untuk model pembelajaran penemuan dan model pembelajaran inkuiri terbimbing dari kesadaran metakognitif rendah adalah 69,16. Untuk membuktikan pengaruh model pembelajaran dan kesadaran metakognisi terhadap hasil belajar dan signifikansi perbedaan rata-rata hasil belajar kesadaran metakognisi tinggi dan kesadaran metakognisis rendah, data dianalisis dengan menggunakan análisis varian dua arah GLA'I (General Liniear Model) Univarial.

Deskripsi hasil penelitian ini bertujuan memberikan gambaran hasil belajar peserta didik kelas XI IPA SMA Negeri 2 Takalar. Gambaran ini didasarkan pada Tabel 4.3 yaitu data persentase dan kategori hasil belajar peserta didik baik pada pembagian model pembelajaran maupun pada kesadaran metakognitif peserta didik. Adapun persentase perolehan dan kategori hasil belajar peserta didik dapat dilihat pada Tabel 6.

Tabel 6 Distribusi Persentase Hasil Belajar Peserta Didik

\begin{tabular}{|c|c|c|c|c|c|}
\hline \multirow{3}{*}{ Skor } & \multicolumn{5}{|c|}{ Hasil Belajar Peserta Didik } \\
\hline & \multicolumn{2}{|c|}{$\begin{array}{l}\text { Model Pembelajaran } \\
\text { Discovery Learning }\end{array}$} & \multicolumn{2}{|c|}{$\begin{array}{l}\text { Model Pembelajaran } \\
\text { Inkuiri Terbimbing }\end{array}$} & \multirow{2}{*}{ Kategori } \\
\hline & $\begin{array}{l}\text { Frekuen } \\
\text { si }\end{array}$ & Persentase & Frekuensi & Persentase & \\
\hline $\begin{array}{l}0-39 \\
40-59 \\
60-74 \\
75-90 \\
91-100\end{array}$ & $\begin{array}{c}1 \\
2 \\
14 \\
16 \\
1\end{array}$ & $\begin{array}{c}2,8 \\
5,6 \\
38,9 \\
44,4 \\
2,8\end{array}$ & $\begin{array}{c}1 \\
5 \\
19 \\
7 \\
1\end{array}$ & $\begin{array}{c}3,0 \\
15,2 \\
57,6 \\
21,2 \\
3,0\end{array}$ & $\begin{array}{c}\text { Sangat } \\
\text { Rendah } \\
\text { Rendah } \\
\text { Sedang } \\
\text { Tinggi } \\
\text { Sangat } \\
\text { Tinggi }\end{array}$ \\
\hline
\end{tabular}

Pada Tabel 7 distribusi frekuensi dan kategori hasil belajar peserta didik terlihat bahwa pada kelas yang diajar dengan model pembelajaran penemuan, peserta didik yang hasil belajarnya sangat rendah adalah 1 orang atau 2,8 $\%$, rendah adalah 2 orang atau 5,6 \%, sedang adalah 14 orang atau 38,9\%, tinggi adalah 16 orang atau $44,4 \%$ dan yang sangat tinggi adalah 1 orang atau 2,8
$\%$. Pada kelas yang diajar dengan menggunakan model pembelajaran inkuiri terbimbing, peserta didik yang hasil belajarnya sangat rendah adalah 1 orang atau $3,0 \%$, rendah adalah 5 orang atau $15,2 \%$, sedang adalah 19 atau 57,6 \%, tinggi adalah 7 orang atau $21,2 \%$ dan sangat tinggi adalah 1 orang atau $3,0 \%$. Adapun diagram batang distribusi persentase hasil belajar peserta didik dapat dilihat pada Gambar 1 


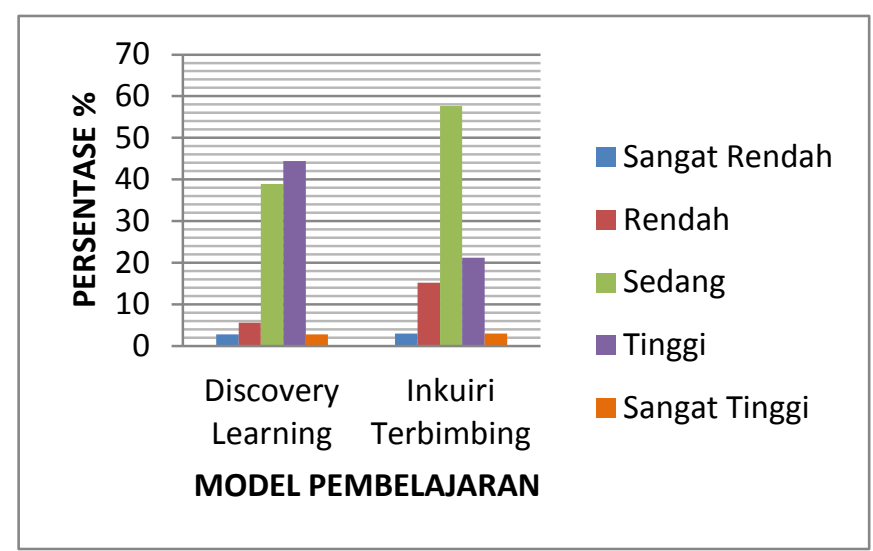

Gambar 1 Diagram Batang Distribusi Persentase Hasil Belajar Peserta Didik diperoleh distribusi ketuntasan

Skor rata-rata dikelompokkan dalam dua hasil belajar seperti yang telihat pada Tabel 7

kategori menurut kriteria ketuntasan yang digunakan di SMA Negeri 2 Takalar sehingga

Tabel 7 Distribusi Ketuntasan Hasil Belajar Peserta didik SMA Negeri 2 Takalar

\begin{tabular}{|c|c|c|c|c|c|c|}
\hline \multirow{2}{*}{ No. } & \multirow{2}{*}{ Kategori } & \multirow{2}{*}{ KKM } & \multicolumn{2}{|c|}{ Discovery Learning } & \multicolumn{2}{|c|}{ Inkuiri Terbimbing } \\
\hline & & & Fre-kuensi & Per-sentase & Freku-ensi & $\begin{array}{l}\text { Per-sen- } \\
\text { tase }\end{array}$ \\
\hline \multirow{3}{*}{$\begin{array}{l}1 . \\
2 .\end{array}$} & Tuntas & $70-100$ & 31 & 91,2 & 23 & 69,7 \\
\hline & $\begin{array}{l}\text { Tidak } \\
\text { Tuntas }\end{array}$ & $0-69$ & 3 & 8,8 & 10 & 30,3 \\
\hline & Jumlah & & 34 & 100,0 & 33 & 100,0 \\
\hline
\end{tabular}

Pada Tabel 7 distribusi frekuensi dan kategori ketuntasan belajar peserta didik terlihat bahwa pada kelas yang diajar dengan menggunakan model pembelajaran penemuan, peserta didik yang tuntas adalah 31 orang $(91,2 \%)$, sedangkan yang tidak tuntas adalah 3 orang $(8,8 \%)$. Pada kelas yang diajar dengan menggunakan model pembelajaran inkuiri terbimbing, persentase ketuntasan peserta didik adalah 23 orang ( 69,7 $\%)$, dan yang tidak tuntas adalah 10 orang (30,3 $\%)$. Adapun diagram batang ketuntasan hasil belajar peserta didik dapat dilihat pada gambar 2

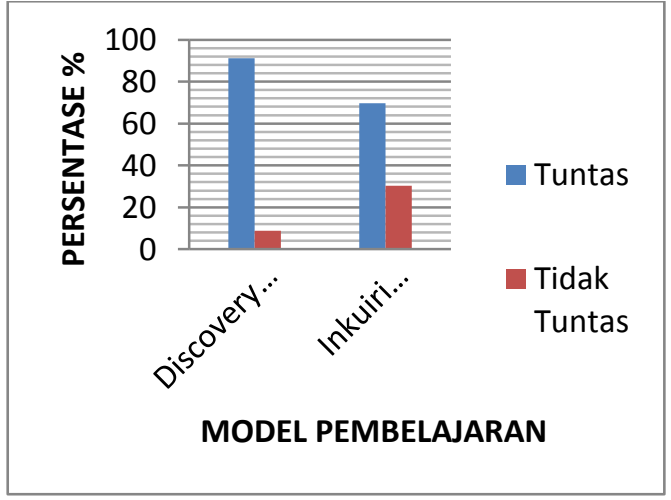

Gambar 2 Diagram Batang Distribusi Persentase Ketuntasan Hasil Belajar Peserta didik

b. Deskripsi Ketuntasan Butir Soal Hasil belajar 
Kemampuan peserta didik dalam menyelesaikan tiap butir soal hasil belajar disajikan dalam Tabel 4.5 yang didalamnya berisi tentang deskripsi ketuntasan tiap butir soal hasil belajar peserta didik.

Tabel 8 Ketuntasan Tiap Butir Soal Hasil Belajar Peserta Didik

\begin{tabular}{|c|c|c|}
\hline \multirow[b]{2}{*}{$\begin{array}{l}\text { Butir } \\
\text { Soal }\end{array}$} & \multicolumn{2}{|c|}{$\begin{array}{c}\text { Persentase Ketuntasan Peserta } \\
\text { Didik }\end{array}$} \\
\hline & $\begin{array}{c}\text { Model } \\
\text { Pembelajaran } \\
\text { Discovery } \\
\text { Learning }\end{array}$ & $\begin{array}{c}\text { Model } \\
\text { Pembelajaran } \\
\text { Inkuiri } \\
\text { Terbimbing }\end{array}$ \\
\hline 1 & 94,1 & 87,9 \\
\hline 2 & 58,8 & 54,5 \\
\hline 3 & 97,1 & 51,5 \\
\hline 4 & 97,1 & 66,7 \\
\hline 5 & 64,7 & 93,9 \\
\hline
\end{tabular}

Tabel 8 menggambarkan ketuntasan belajar peserta didik untuk tiap butir soal hasil belajar. Kelas yang diajar dengan menggunakan model pembelajaran penemuan, untuk butir soal 1, 3 dan 4, mampu dijawab oleh peserta didik dengan persentase diatas KKM (73) sedangkan kelas yang diajar dengan menggunakan model pembelajaran inkuiri terbimbing untuk butir soal 1 dan 5 yang mampu dijawab oleh peserta didik dengan persentase diatas KKM (73). Dengan demikian secara keseluruhan peserta didik yang diajar dengan menggunakan model pembelajaran penemuan nilai ketuntasannya lebih besar dibandingkan dengan peserta didik yang diajar dengan menggunakan model pembelajaran inkuiri terbimbing.

Peserta didik yang diajarkan dengan menggunakan model pembelajaran inkuiri terbimbing, umumnya peserta didik merasa kesulitan untuk menyelesaikan soal nomor 2. Hal ini di buktikan dengan skor yang diperoleh untuk soal nomor 2 di bawah skor ketuntasan minimal. Kelas yang diajar dengan menggunkan model pembelajaran inkuiri terbimbing peserta didik hanya mampu menjawab item soal nomor 1 dan 5 sedangkan untuk item soal nomor 2, 3 dan 4 peserta didik merasa kesulitan untuk dapat menyelesaikannya dengan benar. Hal ini di bukuktikan skor yang diperoleh di bawah skor ketuntasan minimal.

\section{Pengujian Analisis Prsyarat}

Sebelum melakukan analisis statistik inferensial, maka sebagal uji prasyarat analisis dilalukan uji normalitas dan uji homogenitas dengan bantuan program SPSS 20. Jika uji prasyarat memenuhi kriteria normal dan homogen maka digunakan statistik parametrik, sebaliknya jika kriteria normal dan homogen tidak terpenuhi maka digunakan statistik nonparametrik.

Uji normalitas digunakan untuk mengetahui apakah data yang diteliti berasal dari populasi yang terdistribusi normal. Pengujian normalitas dihitung dengan bantuan program SPSS 20 menggunakan analisis one-samplekolmogorov-smirnov test. Bentuk hipotesis untuk uji normalitas adalah sebagai berikut:

$\mathrm{H}_{0}$ : angka signifikan (Sig) > 0,05 maka data berdistribusi normal

$\mathrm{H}_{1}$ : angka signifikan $(\mathrm{Sig})<0,05$ maka data tidak berdistribusi normal

Dengan kriteria pengujian ini: apabila signifikansi $(\rho)$ yang diperoleh lebih besar dari $\alpha$ $=0,05$ berarti $\mathrm{H}_{1}$ ditolak dan $\mathrm{H}_{0}$ diterima, maka data tersebut berasal dari populasi yang terdistribusi normal. Uji normalitas menunjukkan peserta didik dalam populasi tersebut berada dalam kategori memiliki pengetahuan yang sama secara keseluruhan atau tidak. Jika tidak terdistribusi normal dapat diartikan bahwa hampir semua peserta didik dalam populasi tersebut tingkat pengetahuannya sama, sebaliknya jika terdistribusi normal dapat diartikan bahwa setiap peserta didik dalam populasi tersebut memiliki tingkatan pengetahuan yang berbeda-beda. Kelas pada model pembelajaran penemuan dan inkuiri terbimbing nilai sig $0,20>0,05$ berarti $\mathrm{H}_{1}$ ditolak dan $\mathrm{H}_{0}$ diterima, maka hasil belajar pada kelas dengan kedua model pembelajaran tersebut terdistribusi normal, selengkapnya dapat dilihat pada Tabel 9.

Tabel 9 Hasil Analisis Normalitas Nilai Hasil belajar Peserta didik yang dengan Model Pembelajaran Berbasis Masalah dan Pembelaj aran Langsung

\begin{tabular}{|c|c|c|c|c|}
\hline & \multirow[b]{2}{*}{$\begin{array}{c}\text { Model } \\
\text { Pembelajaran }\end{array}$} & \multicolumn{3}{|c|}{ Kolmogorov-Sinirnov ${ }^{\mathrm{a}}$} \\
\hline & & $\begin{array}{c}\text { Statisti } \\
\text { c }\end{array}$ & $\mathrm{df}$ & Sig. \\
\hline $\begin{array}{c}\text { Hasil } \\
\text { Belaj } \\
\text { ar }\end{array}$ & $\begin{array}{l}\text { Discovery } \\
\text { Learning dan } \\
\text { Inkuiri } \\
\text { Terbimbing }\end{array}$ & 0,086 & 67 & 0,200 \\
\hline
\end{tabular}


Uji homogenitas digunakan untuk mengetahui apakah kedua sampel yang diambil berasal dan populasi yang homogen. Pengujian homoginitas dihitung dengan bantuan program SPSS 20 menggunakan analisis Levene's Test of Equality of Error Variance. Dengn kriteria pengujian: jika signifikansi ( $\rho$ ) yang diperoleh lebih besar dari $\alpha=0,05$ maka data tersebut homogen.

Hasil pengujian homogenitas menunjukkan bahwa nilai sig 0,104 > 0,05 artinya $\mathrm{H}_{1}$ ditolak dan $\mathrm{H}_{0}$ diterima. Sehingga dapat disimpulkan bahwa nilai hasil belajar peserta didik berasal dari populasi yang homogen, selengkapnya dapat dilihat pada Tabel 10

Tabel 10 Hasil Analisis Uji Homogenitas untuk Nilai Hasil belajar

\begin{tabular}{l|c|c|c|l}
\hline & $\begin{array}{l}\text { Levene } \\
\text { Statistic }\end{array}$ & df1 & df2 & Sig. \\
\hline Hasil Belajar & 2,141 & 3 & 63 & 0,104 \\
\hline
\end{tabular}

\section{Pengujian Hipotesis}

Uji prasyarat telah dilakukan dan diperoleh data yang berdistribusi normal dengan populasi yang homogen, maka dilanjutkan dengan uji hipotesis. Hasil pengujian hipotesis merupakan jawaban dan masalah 1, 2 dan 3. pengujian hipotesis dengan menggunakan analisis Anacova. Adapun hasil pengujian hipotesis (lampiran 11. b) dapata dilihat pada Tabel 11

Tabel 11 Hasil Analisis Anacova

\begin{tabular}{l|c|c}
\hline \multicolumn{1}{c|}{ Sumber } & F & Sig \\
\hline Model Pembelajaran & $1791,144^{\mathrm{a}}$ & 0,002 \\
Kesadaran Metakognitif & 608,475 & 0,019 \\
Model & 787,578 & 0,008 \\
Pembelajaran*Kesadaran & & \\
Metakognitif & & \\
\hline
\end{tabular}

1) Hipotesis I

hipotesis statistiknya:

$\mathrm{H}_{0}: \mu_{A_{1}}=\mu_{A_{2}}$

$\mathrm{H}_{1}: \mu_{A_{1}} \neq \mu_{A_{2}}$

Kriteria pengujian: Jika $p \geq \alpha(0,05)$

maka $\mathrm{H}_{0}$ diterima. Hasil analisis menunjukkan bahwa nilai sig $0,002<\alpha=$ 0,05 berarti $\mathrm{H}_{0}$ ditolak dan $\mathrm{H}_{1}$ diterima artinya terdapat perbedaan hasil belajar peserta didik kelas XI IPA SMA Negeri 2
Takalar yang menggunakan model pembelajaran penemuan dan model pembelajaran inkuiri terbimbing pada materi pokok asam basa.

2) Hipotesis II

hipotesis statistiknya:

$\mathrm{H}_{0}: \mu_{B_{1}}=\mu_{B_{2}}$

$\mathrm{H}_{1}: \mu_{B_{1}} \neq \mu_{B_{2}}$

Kriteria pengujian: Jika $\mathrm{p} \geq \alpha(0,05)$

maka $\mathrm{H}_{0}$ diterima. Hasil analisis menunjukkan bahwa nilai sig $0,019<\alpha=$ 0,05 berarti $\mathrm{H}_{0}$ ditolak dan $\mathrm{H}_{1}$ diterima artinya terdapat perbedaan hasil belajar peserta didik kelas XI IPA SMA Negeri 2 Takalar yang memiliki kesadaran metakognitif tinggi dan kesadaran metakognitif rendah pada materi pokok asam basa.

3) Hipotesis III

hipotesis statistiknya:

$\mathrm{H}_{0}: \mu_{A_{1 B_{1}}}-\mu_{A_{1 B_{2}}}=\mu_{A_{2 B_{1}}}-\mu_{A_{2 B_{2}}}$

$\mathrm{H}_{1}: \mu_{A_{1 B_{1}}}-\mu_{A_{1 B_{2}}} \neq \mu_{A_{2 B_{1}}}-\mu_{A_{2 B_{2}}}$

Kriteria pengujian: Jika $\mathrm{p} \leq \alpha(0,05)$, maka $\mathrm{H}_{1}$ diterima. Hasil analisis menunjukkan bahwa nilai signifikan $0,008<\alpha=0,05$ berarti $\mathrm{H}_{0}$ ditolak dan $\mathrm{H}_{1}$ diterima artinya terdapat perbedaan selisih antara hasil belajar peserta didik pada kesadaran metakognitif tinggi dan kesadaran metakognitif rendah yang menggunakan model pembelajaran penemuan dengan selisih hasil belajar peserta didik pada kesadaran metakognitif tinggi dan kesadaran metakognitif rendah yang menggunakan model pembelajaran inkuiri terbimbing. Oleh karena itu, adanya perbedaan selisih antara hasil belajar peserta didik yang memiliki kesadaran metakognitif tinggi dan kesadaran metakognitif rendah pada pembelajaran penemuan dengan hasil belajar peserta didik yang memiliki kesadaran metakognitif tinggi dan kesadaran metakognitif rendah pada pembelajaran inkuiri terbimbing maka dapat disimpulkan bahwa diperoleh interaksi antara model pembelajaran dengan kesadaran metakognitif dalam mempengaruhi hasil belajar peserta didik. Hipotesis ketiga juga dapat dijelaskan dengan grafik seperti pada Gambar 3 


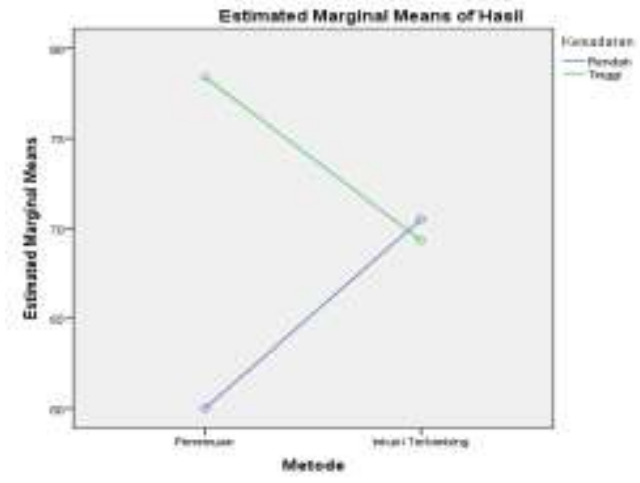

Gambar 3. Interaksi Antara Model Pembelajaran dengan Kesadaran Metakognitif peserta didik kelas XI IPA SMA Negeri 2 Takalar

Ada atau tidak adanya interaksi antara model pembelajaran dan kesadaran metakognitif dapat ditunjukkan oleh grafik pada Gambar 4.3 dan interaksi terjadi jika ada perpotongan garis antara model pembelajaran penemuan dengan model pembelajaran inkuiri terbimbing pada peserta didik yang memiliki kesadaran metakognitif tinggi dan kesadaran metakognitif rendah sebaliknya tidak ada interaksi jika tidak ada perpotongan garis. Pada gambar diatas memperlihatkan bahwa ada perpotongan garis antara model pembelajaran penemuan dan model pembelajaran inkuiri terbimbing maka dapat disimpulkan bahwa ada interaksi antara model pembelajaran dengan kesadaran metakognitif dalam mempengaruhi hasil belajar peserta didik kelas XI 1PA SMA Negeri 2 Takalar pada materi pokok asam basa.

\section{Pembahasan}

Penelitian ini bertujuan untuk mengetahui pengaruh model pembelajaran dan kesadaran metakognitif terhadap hasil belajar peserta didik kelas XI IPA SMA Negeri 2 Takalar. Berdasarkan pada rumusan masalah (1, 2 dan 3) bahwa pengaruh perlakuan terhadap hasil belajar secara operasional dapat dilihat dan perbedaan hasil belajar peserta didik dan kelompok yang dibandingkan. Sehingga dalam pembahasan ini perbedaan-perbedaan tersebut akan dikembalikan kepengertian pengaruh. Dalam artian bahwa jika ada perbedaan maka ada pengaruh.

Tabel 4.1 memberikan gambaran mengenai hasil belajar peserta didik kelas XI IPA SMA Negeri 2 Takalar pada materi pokok asam basa. Hasil analisis deskriptif data penelitian tentang hasil belajar peserta didik pada setiap kelas eksperimen menunjukkan bahwa nilai rata-rata hasil belajar peserta didik yang diajar dengan menggunakan model pembelajaran penemuan $(76,24)$ lebih tinggi dibandingkan dengan nilai peserta didik yang diajar dengan menggunakan model pembelajaran inkuiri terbimbing $(70,30)$. Berdasarkan pada kategori hasil belajar, rata-raa nilai hasil belajar peserta didik yang diajar dengan menggunakan model pembelajaran penemuan berada pada kategori tinggi, sedangkan nilai hasil belajar peserta didik yang diajar dengan menggunakan model pembelajaran inkuiri terbimbing berada pada kategori sedang. Hal seperti ini dapat terjadi karena karakteristik peserta didik cukup berbeda pada kedua kelas eksperimen. Misalnya, model pembelajaran penemuan diterapkan pada peserta didik kelas XI IPA 1 sedangkan model inkuiri terbimbing diterapkan pada peserta didik kelas XI IPA 2. Selanjutnya, di lapangan diketahui bahwa karakteristik pengetahuan yang dimiliki peserta didik pada kelas XI IPA 1 lebih baik dibandingkan dengan peserta didik pada kelas XI IPA 2. Jadi, adanya perbedaan karakteristik ini disimpulkan bahwa nilai hasil belajar dapat dikategorikan tinggi dan sedang pada peserta didik kelas XI IPA SMA Negeri 2 Takalar.

Hasil penelitian yang diperoleh menunjukkan adanya perbedaan nilai rata-rata hasil belajar peserta didik kelas XI IPA SMA Negeri 2 Takalar. Hal ini disebabkan adanya pengaruh dari kedua model pembelajaran yang digunakan yaitu model pembelajaran penemuan dan model pembelajaran inkuiri terbimbing. Meskipun model pembelajaran penemuan dan inkuiri terbimbing merupakan model pembelajaran yang sama-sama berpusat pada peserta didik (Student-Centre) namun terdapat perbedaan dari segi pelaksaan kedua model pembelajaran tersebut. Misalnya, dari segi penyajian masalah pada model pembelajaran penemuan dapat direkayasa oleh guru dan hal ini menjadi keunikan tersendiri yang dapat membuat daya tarik peserta didik dalam proses pembelajaran sedangkan penyajian masalah tidak direkayasa pada model pembelajaran inkuiri terbimbing. Oleh karena adanya perbedaan dari segi pelaksanaannya meskipun sudut pandang pembelajarannya sama, maka akan berpengaruh juga terhadap hasil belajar peserta didik. 
Model pembelajaran penemuan dalam proses pembelajarannya lebih mengaktifkan peserta didik dalam menemukan konsep atau prinsip dari suatu materi pembelajaran. Peserta didik diarahkan untuk menggunakan proses mentalnya untuk menemukan beberapa konsep dan prinsip. Guru dalam model pembelajaran ini lebih bersifat memberikan mengarahkan kepada peserta didik sehingga lebih terlatih dalam menganalisis, mengevaluasi dalam menyelesaikan soal-soal yang diberikan kepada peserta didik yang secara tidak langsung berpengaruh terhadap hasil belajar peserta didik.

Model pembelajaran inkuiri terbimbing dalam proses pembelajarannya mempunyai prinsip yang sama dengan pembelajaran penemuan (Discovery Learning). Tidak ada perbedaan yang prinsipil pada kedua model pembelajaran ini, pada pembelajaran penemuan lebih menekankan pada ditemukannya konsep dan prinsip yang sebelumnya tidak diketahui. Perbedaanya dengan pembelajaran penemuan bahwa permasalahan yang diperhadapkan kepada peserta didik semacam masalah yang direkayasa oleh guru, sedangkan pada pembelajaran inkuiri terbimbing permasalahannya bukan hasil rekayasa, sehingga peserta didik harus mengerahkan seluruh pikirannya dan keterampilannya untuk mendapatkan temuan-temuan tersebut melalui proses penelitiannya sehingga lahirlah sebuah konsep dan prinsip berdasarkan tujuan pembelajaran yang diajarkan pada saat itu.

Hasil belajar peserta didik ditinjau dari kesadaran metakognitif peserta didik yang yang diajar dengan menggunakan model pembelajaran penemuan yang memiliki kesadaran metakognitif tinggi berada pada kategori tinggi dan peserta didik yang memiliki kesadaran metakognitif rendah berada pada kategori sedang. Peserta didik yang diajar dengan menggunakan model pembelajaran inkuiri terbimbing yang memiliki kesadaran metakognitif tinggi dan kesadaran metakognitif rendah berada pada kategori sedang.

Peserta didik yang memiliki kesadaran metakognitif tinggi pada pembelajaran penemuan berada pada kategori tinggi sedangkan pada pembelajaran inkuiri terbimbing berada pada kategori sedang. Perbedaan ini diakibatkan karena adanya pengaruh dari model pembelajaran dan karekteristik peserta didik itu sendiri. Model pembelajaran penemuan dan inkuiri terbimbing sangat mendukung peserta didik yang memiliki kesadaran metakognitif karena peserta didik mampu menggunakan proses berpikir dalam berpikir lancar, berpikir luwes, berpikir orisinal dan berpikir elaboratif sehingga dapat mempengaruhi hasil belajar. Adanya perbedaan ini disebabkan karakteristik dasar peserta didik sehingga lahirlah peserta didik dengan kesadaran metakognitif tinggi dan kesadaran metakognitif rendah yang nantinya akan memberikan pengaruh pada proses pelakasanaan kedua model pembelajaran tersebut. Oleh karena itu, akan diperoleh peserta didik yang mampu memiliki hasil belajar yang baik maupun yang kurang baik sehingga mampu mempengaruhi ketuntasan hasil belajar peserta didik kearah yang lebih baik pada kelas XI IPA 1 dan IPA 2 di SMA Negeri 2 Takalar dalam materi pokok asam basa. Adapun persentase ketuntasan hasil belajar kelas IPA 1 (penemuan) lebih tinggi yaitu 91,2\% dibandingkan dengan ketuntasan hasil belajar kelas IPA 2 (inkuiri terbimbing) yaitu 69,7\% menunjukkan bahwa hasil belajar peserta didik kelas IPA 1 yang diajar dengan menggunakan model pembelajaran penemuan lebih baik dibandingkan dengan hasil belajar peserta didik kelas IPA 2 yang diajar dengan menggunakan model pembelajaran inkuiri terbimbing. Hal ini disebabkan peserta didik pada kelas IPA 1 mayoritas memiliki kesadaran metakognitif tinggi dibandingkan dengan peserta didik pada kelas IPA 2 yang memiliki kesadaran metakognitif rendah. Diketahui bahwa dengan kesadaran metakognitif tinggi mampu mempengaruhi hasil belajar peserta didik kearah yang lebih baik dibandingkan dengan kesadaran metakognitif rendah. Selain itu, perbedaan ketuntasan hasil belajar yang diperoleh disebabkan karakteristik peserta didik yang berbeda pada kelas IPA 1 dan IPA 2. Meskipun ketuntasan hasil belajar yang diperoleh berbeda, namun hasil belajar yang diperoleh cukup mengalami perubahan kearah yang lebih baik dari sebelumnya.

\section{Perbedaan Hasil Belajar Peserta Didik Ditinjau dari Model Pembelajaran}

Nilai rata-rata hasil belajar peserta didik berdasarkan hasil analisis statistik deskriptif diperoleh bahwa peserta didik yang diajar dengan menggunakan model pembelajaran penemuan adalah 76,24 dan nilai hasil belajar peserta didik yang telah diajar dengan menggunakan model pembelajaran inkuiri 
terbimbing adalah 70,30. Hasil belajar yang diajar dengan menggunakan model pembelajaran penemuan lebih tinggi daripada hasil belajar yang diajar dengan menggunakan model pembelajaran inkuiri terbimbing. Hal ini menunjukan bahwa model pembelajaran penemuan lebih baik jika dibandingkan dengan model pembelajaran inkuiri terbimbing.

Hasil analisis inferensial diperoleh nilai signifikan $0,002<0,05$ berarti $\mathrm{H}_{0}$ ditolak dan $\mathrm{H}_{1}$ diterima. Sehingga dapat disimpulkan bahwa ada perbedaan hasil belajar antara peserta didik yang diajar dengan model pembelajaran penemuan dengan peserta didik yang diajar dengan model pembelajaran inkuiri terbimbing pada materi pokok asam basa di kelas XI IPA SMA Negeri 2 Takalar. Adanya perbedaan terhadap hasil hasil belajar peserta didik berarti adanya pengaruh atau dapat dikatakan bahwa ada pengaruh model pembelajaran terhadap hasil belajar hasil belajar peserta didik.

Model pembelajaran penemuan dan model pembelajaran inkuiri terbimbing mempunyai kesamaan yaitu keduanya mengarah pada keterlibatan peserta didik secara aktif untuk meningkatkan prestasi belajar. Keduanya memiliki persamaan yaitu menekankan pada keaktifan peserta didik melalui kelompok belajar tetapi berbeda dalam hal pelaksanaannya. Model pembelajaran penemuan memberikan hasil belajar yang lebih tinggi dari model pembelajaran inkuiri terbimbing, khususnya pada materi pokok asam basa. Hal ini terjadi karena dalam model pembelajaran penemuan, peserta didik mampu memperbaiki dalam meningkatkan keterampilan-kerampilan dalam proses belajarnya, misalnya usaha penemuan yang dilakukan tergantung pada bagaiman cara belajar peserta didik tersebut. Oleh karena itu, pengetahuan yang ditemukan dalam hal ini bersifat sangat pribadi dan ampuh sehingga mampu menguatkan pengertian, ingatan, dan transfer yang baik. Hal ini merupakan suatu kesenangan tersendiri karena peserta didik berhasil dan percaya dalam menemukan suatu konsep dan prinsip karena mampu bekerjasama dengan yang lainnya dalam satu kelompok. Model ini mampu membuat peserta didik berkembang dengan cepat sesuai kecepatannya sendiri sehingga dapat menciptakan cara belajar dan memotivasi diri sendiri.

Model pembelajaran inkuiri terbimbing merupakan suatu model pembelajaran yang prinsip dasarnya tidak jauh berbeda dengan model pembelajaran penemuan hanya saja pada model inkuiri terbimbing mengaharuskan peserta didik untuk mengerahkan seluruh pikiran dan keterampilannya dalam menemukan konsep dan prinsip dari suatu materi pelajaran karena permasalahan yang disajikan bukan hasil rekayasa guru. Model pembelajaran ini guru akan terus membimbing peserta didik dalam menyimpulkan konsep dan prinsip dari suatu materi pokok pelakajaran sehingga proses pembelajaran terkadang ditemukan sulit mengembangkan sosial peserta didik yang pada akhirnya akan mengalami kejenuhan, perhatian yang tidak fokus dan pembelajaran mereka akan terlambat. Model pembelajaran inkuiri terbimbing masih melibatkan seorang guru misalnya dalam menentukan bahan dan alat yang akan digunakan dalam praktikum, peserta didik akan merasa kurang percaya diri dan apabila peserta didik diberikan suatu masalah atau tugas dalam kelas peserta didik kadang merasa kesulitan untuk menyelesaikan atau mengerjakan sendiri tanpa bantuan teman-temannya dan akibatnya hasil hasil belajar peserta didik rendah. Sebaliknya pada model pembelajaran penemuan seorang guru dapat membaur dengan peserta didik atau guru dapat bertindak sebagai peserta didik dalam menyimpulkan konsep dan prinsip yang diperoleh.

\section{Perbedaan Hasil Belajar Peserta Didik Ditinjau dari Kesadaran Metakognitif Hasil analisis inferensial} memperlihatkan bahwa signifikansi yang diperoleh $0,019<0,05$. Hasil ini menyebabkan $\mathrm{H}_{0}$ ditolak dan $\mathrm{H}_{1}$ diterima yaitu ada perbedaan hasil belajar peserta didik yang memiliki kesadaran metakognitif tinggi dan kesadaran metakognitif rendah pada materi pokok asam basa di kelas XI IPA SMA Negeri 2 Takalar.

Rata-rata hasil hasil belajar peserta didik yang diajar dengan model pembelajaran penemuan yang memiliki kesadaran metakognitif tinggi dan kesadaran metakognitif rendah berturut-turut 78,40 dan 60,00 . Hasil belajar peserta didik pada model pembelajaran inkuiri terbimbing yang memiliki kesadaran metakognitif tinggi dan kesadaran metakognitif rendah berturut-turut 69,33 dan 70,52. Hasil ini memperlihatkan bahwa peserta didik yang kesadaran metakognitif tinggi memiliki hasil belajar yang tinggi. Sebaliknya peserta didik yang memiliki kesadaran metakognitif rendah 
mendapatkan hasil belajar yang rendah. Adanya perbedaan hasil belajar antara peserta didik yang memiliki kesadaran metakognitif tinggi dan kesadaran metakognitif rendah menunjukan adanya pengaruh atau dapat dikatakan bahwa ada pengaruh kesadaran metakognitif terhadap hasil belajar peserta didik.

Kesadaran metakognitif merupakan kesadaran berpikir seseorang tentang berpikirnya sendiri. Peserta didik yang menggunakan kesadaran metakognitif dalam pembelajarannya akan merancang apa yang hendak dipelajari, memantau perkembangan diri dalam belajar dan menilai apa yang dipelajari, sehingga peserta didik secara sadar mengontrol proses berpikir dan pembelajaran yang dilakukan. Dengan menerapkan kesadaran metakognitif maka peserta didik akan mampu mengontrol kelemahan diri dalam belajar dan kemudian akan memperbaiki kelemahan tersebut, dapat menentukan cara belajar yang tepat sesuai dengan kemampuannya sendini, dapat menyelesaikan masalah-masalah dalam belajar baik yang berkaitan dengan soal-soal yang diberikan oleh guru dan dapat memahami sejauh mana keberhasilan yang telah dicapai dalam belajar.

Rata-rata hasil belajar peserta didik yang memiliki kesadaran metakognitif tinggi memperlihatkan hasil belajar yang lebih tinggi pada model pembelajaran penemuan. Hasil ini berkaitan dengan kesadaran metakognitif peserta didik dalam memecahkan suatu masalah yaitu memahami masalah, menggunakan atau menerapkan model yang direncanakan dan menilai hasil pekerjaan. Kesadaran metakognitif memiliki peranan penting dalam menyelesaikan masalah, khusunya dalam mengatur dan mengontrol aktifitas kognitif peserta didik dalam menyelesaikan masalah menjadi lebih efektif dan efesien. Hal ini berarti peserta didik yang memiliki kesadaran metakognitif tinggi akan memiliki kesadaran belajar yang tinggi sehingga akan memperoleh hasil belajar yang lebih baik.

3. Perbedaan selisih antara hasil belajar peserta didik kesadaran metakognitif tinggi dan kesadaran metakognitif rendah pada pembelajaran penemuan dengan selisih hasil belajar peserta didik kesadaran metakognitif tinggi dan kesadaran metakognitif rendah pada pembelajaran inkuiri terbimbing
Hasil analisis statistik deskriptif menunjukkan bahwa pada kelas yang diajar dengan model pembelajaran penemuan yang memiliki nilai rata-rata hasil belajar tinggi adalah peserta didik yang memiliki kesadaran metakognitif tinggi sedangkan peserta didik yang diajar dengan model pembelajaran inkuiri terbimbing yang memiliki nilai rata-rata hasil belajar rendah adalah peserta didik yang memiliki kesadaran metakognitif rendah.

Hasil analisis inferensial diperoleh nilai signifikan 0,008 $<0,05$ berarti Ho ditolak dan $\mathrm{H}_{1}$ diterima, ini menandakan adanya perbedaan antara selisih hasil belajar peserta didik kesadaran metakognitif tinggi dan kesadaran metakognitif rendah pada pembelajaran penemuan dengan selisih hasil belajar peserta didik kesadaran metakognitif tinggi dan kesadaran metakognitif rendah pada pembelajaran inkuiri terbimbing peserta didik kelas Xl IPA SMA Negeri 2 Takalar. Jika ada perbedaan hasil belajar antara kesadaran metakognitif dengan model pembelajaran, maka ada interaksi antara model pembelajaran dan kesadaran metakognitif dalam mempengaruhi hasil belajar. Dapat juga dikatakan bahwa model pembelajaran yang digunakan saling mempengaruhi hasil belajar peserta didik yang mempunyai kesadaran metakognitif tinggi dan yang mempunyai kesadaran metakognitif rendah.

Pada Gambar 4.3 menunjukkan bahwa peserta didik dengan kesadaran metakognitif tinggi memiliki hasil belajar yang lebih tinggi dibanding dengan peserta didik yang memiliki kesadaran metakognitif rendah untuk masingmasing model pembelajaran yang digunakan. Kedua garis nampak terjadi perpotongan sehingga dapat disimpulkan bahwa ada interaksi antara model pembelajaran yang digunakan dengan kesadaran metakognitif dalam mempengaruhi hasil belajar. Peserta didik yang mempunyai kesadaran metakognitif tinggi akan mempunyai nilai yang lebih tinggi dengan yang diajar menggunakan model pembelajaran penemuan maupun yang diajar dengan model pembelajaran inkuiri terbimbing. Peserta didik yang yang mempunyai kesadaran metakognitif tinggi tidak masalah diajar dengan menggunakan model pembelajaran apapun karena peserta didik mampu mengontrol, memantau dan mengendalikan diri dalam proses pembelajaran. Selain itu, dapat diketahui pula bahwa model pembelajaran penemuan lebih baik diterapkan 
pada peserta didik yang memiliki kesadaran metakognitif tinggi dibandingkan pada peserta didik dengan kesadaran metakognitif rendah. Hal ini dapat dilihat dari nilai rata-rata hasil belajar peserta didik dengan kesadaran metakognitif tinggi dan rendah yaitu 78,40 dan 60,00 . Sedangkan, model pembelajaran inkuiri terbimbing lebih baik diterapkan pada peserta didik dengan kesadaran metakognitif rendah dibandingkan pada peserta didik dengan kesadaran metakogntif tinggi. Hal ini dapat dilihat dari nilai rata-rata hasil belajar peserta didik dengan kesadaran metakognitif tinggi dan rendah yaitu 69,33 dan 70,52. Adapaun nilai total rata-rata hasil belajar peserta didik yang diajar dengan menggunakan model pembelajaran penemuan dan inkuiri terbimbing yaitu 76,24 dan 70,30 serta nilai total rata-rata hasil belajar peserta didik yang memiliki kesadaran metakognitif tinggi dan rendah yaitu 76,89 dan 69,16. Jadi, dapat disimpulkan bahwa hasil belajar peserta didik yang diajar dengan model pembelajaran penemuan lebih baik dibandingkan dengan model pembelajaran inkuiri terbimbing serta hasil belajar peserta didik yang memiliki kesadaran metakognitif tinggi lebih baik dibandingkan dengan peserta didik yang memiliki kesadaran metakognitif rendah. Oleh karena itu, terjadi interaksi antara model pembelajaran dan kesadaran metakognitif dalam mempengaruhi hasil belajar peserta didik SMA Negeri 2 Takalar dalam materi pokok asam basa.

\section{Keterkaitan dengan Teori dan Penelitian yang Pernah Ada}

Sehubungan dengan telah dilakukannya penelitian tersebut ternyata dapat memberikan gambaran yaitu hal ini sejalan dengan penelitian yang pernah dilakukan sebelumnya bahwa (1) ada pengaruh model pembelajaran Inkuiri Terbimbing terhadap hasil belajar kimia peserta didik di kelas XI SMAN 1 Leuwiliang Bogor pada materi laju reaksi, (2) ada pengaruh kesadaran metakognitif terhadap hasil belajar kognitif peserta didik kelas XI IPA SMA Negeri I Segeri dan SMA Negeri 2 Rantepao pada materi pokok larutan penyangga dan asam basa, dan (3) ada pengaruh kesadaran metakognitif terhadap hasil belajar kognitif peserta didik kelas XI IPA SMA Negeri I Sigeri dan SMA Negeri 2 Rantepao pada materi pokok larutan penyangga dan asam basa. Oleh karena itu, hasil yang diperoleh sudah sesuai dengan teori yang menyatakan bahwa dengan kesadaran metakognitif yang tinggi akan memberikan hasil belajar yang baik kepada peserta didik dan kesadaran metakognitif rendah akan memberikan hasil belajar yang rendah pula kepada peserta didik.

\section{SIMPULAN DAN SARAN}

Pada perumusan masalah dikemukakan bahwa pengaruh model pembelajaran dan kesadaran metakognitif terhadap hasil belajar dapat dilihat dari perbedaan rerata yang dibandingkan. Berdasarkan hasil pengujian hipotesis tentang perbedaan-perbedaan yang diambil diatas, maka dapat ditentukan kesimpulan sebagai berikut:

1. Ada pengaruh model pembelajaran terhadap hasil belajar peserta didik kelas XI IPA SMA Negeri 2 Takalar dalam materi pokok asam basa, dalam hal ini rata-rata nilai hasil belajar model pembelajaran penemuan lebih tinggi yaitu 76,24 dibandingkan dengan model pembelajaran inkuiri terbimbing yaitu 70,30 .

2. Ada pengaruh kesadaran metakognitif terhadap hasil belajar peserta didik kelas XI IPA SMA Negeri 2 Takalar dalam materi pokok asam basa, dalam hal ini rata-rata nilai hasil belajar kesadaran metakognitif tinggi lebih baik dibandingkan dengan kesadaran metakognitif rendah.

3. Ada interaksi antara model pembelajaran dan kesadaran metakognitif dalam mempengaruhi hasil belajar. Jadi, ada pengaruh antara model pembelajaran dan kesadaran metakognitif terhadap hasil belajar peserta didik SMA Negeri 2 Takalar dalam materi pokok asam basa.

Berdasarkan kesimpulan dan pembahasan sebelumnya, berikut ini beberapa saran yang diharapkan dapat membantu penelitian selanjutnya:

1. Diharapkan kepada tenaga pendidik agar menerapkan model pembelajaran penemuan untuk peserta didik dengan kesadaran metakognitif tinggi dan model pembelajaran inkuiri terbimbing untuk peserta didik dengan kesadaran metakognitif rendah dalam proses pembelajaran.

2. Diharapkan kepada peneliti lebih lanjut dengan penerapan model ini untuk dapat 
memilih model mana yang lebih baik digunakan pada kondisi tertentu.
Wibowo. 2007. Manajemen Kinerja. Jakarta: PT Rajagrafindo Persada.

\section{DAFTAR RUJUKAN}

Akdon dan Riduwan. 2008. Aplikasi Statistika dan Metode Penelitian untuk Administrasi dan Manajemen. Bandung: Dewa Ruci.

Arikunto. Suharsimi. 2006. Prosedur Penelitian; Suatu Pendekatan Praktek. Jakarta. Rineka Cipta.

Astikasari, Heru. 2011. Metakognisi Dan Theory Of Mind (To-M). Jurnal Psikologi Pitutur, Vol. I, No 2. Juni 2011. Staf Pengajar di Fakultas Psikologi Universitas Kristen Satya Wacana.

Blakey, Elaine dan Spance, Sheila. 2008. Developing Metacognition, (Online), http://www.literacy.kent.edu/ohioeff/res ource.doc, Diakses 25 Mei 2015.

Dahar, Ratna Willis. 2006. Teori-Teori Belajar dan Pembelajaran. Jakarta: Erlangga.

Ghazali, Imam. 2006. Statistik Nonparametrik. Semarang: Badan Penerbit UNDIP.

Hartman, H.J. 2001. Metakognisi dalam pembelajaran dan pengajaran, teori, penelitian dan praktek. Hillsdale, NJ: Lawrence Erlbaum Associates, Inc.

Lingyi, Huang. 2010. Using GPS To Design Narrative-centered Environments for Guided Discovery Learning: "Façade"A Case Study Of A Nonlinear Story, (Online), Vol. 2, $\quad$ No. 64 (http://www.sciencedirect.com, Diakses 23 Januari 2015).

Mulyasa, E. 2004. Kurikulum Berbasis Kompetensi, Konsep, Karakteristik, dan Implementasi. Bandung: PT Remaja Rosdakarya.

Purwanto. 2008. Evaluasi Hasil Belajar. Surabaya: Pustaka Belajar.

Santoso, Singgih. 2008. Statistik Non Parametrik. Jakarta: PT. Elex Media Komoutindo.

Slameto. 2010. Belajar dan Faktor-Faktor yang Mempengaruhinya. Jakarta: PT Rineka Cipta.

Van de Walle, J. A. 2006. Matematika Sekolah Dasar dan Menengah. Pengembangan Pengajaran. Edisi Keenam. Jakarta: Penerbit Erlangga. 